Journal of Agricultural Sciences
(Tarim Bilimieri Dergisi)

\title{
Effects of Normal and Nano-Capsulated Thyme and Peppermint Essential Oils on Intestinal Morphology and Microbial Population of Broilers Fed on Standard and Low Crude Protein Diets
}

\author{
Mohammad Reza ALIE-LALEHa ${ }^{(\mathbb{D}}$, Ali NOBAKHT ${ }^{\mathrm{a} *}$ (D) , Yousef MEHMANNAVAZ $^{\mathrm{a}}$ (D) \\ ${ }^{a}$ Department of Animal Science, Islamic Azad University, Maragheh Branch, Maragheh, IRAN
}

ARTICLE INFO

Research Article

Corresponding Author: Ali NOBAKHT, E-mail: anobakht20@yahoo.com

Received: 25 June 2020 / Revised: 21 July 2020 / Accepted: 21 October 2020 / Online: 20 January 2022

ABSTRACT

This study was conducted to investigate the effects of normal and nanocapsulated forms of thyme and peppermint essential oils on intestinal morphology and microbial population of broilers fed on normal and low crude protein diets. The study was carried out with a total of 320 Ross308 broiler chickens as a $2 \times 2 \times 2(2$ medicinal plant essential oils, 2 forms of oils and 2 levels of diet crude protein) factorial arrangements with 32 groups (10 chicks per replicate) according to a completely random design. This experiment was done in three periods included: Starter (1-10 days), grower (11-24 days) and finisher (25-42 days). The experimental diets had significant effects on intestinal morphology $(\mathrm{P}<0.05)$, so that the use of the usual form of essential oils while reducing the depth of the crypt, increased the ratio of the length of the villa to the depth of the crypt. In use of peppermint essential oil with standard protein, crypt depth increased, and the ratio of villi height to crypt depth was minimal $(\mathrm{P}<0.05)$. A decrease in dietary crude protein level reduced the population of lactobacilli in the intestine $(\mathrm{P}<0.05)$. However, the level of crude protein in the diet and the form of use of the essential oil, as well as the type of essential oil and its form, did not have significant effects on the intestinal microbial population $(\mathrm{P}>0.05)$. Based on the results of this experiment, it can be stated that in broilers, the use of the encapsulated form of thyme essential oil in diets with standard crude protein levels, improved the intestinal morphology and intestinal non-pathogenic microbial population of broilers. Ten percent reduction in dietary crude protein level had adverse effects on measured traits and is not recommended, and in case of reduction of dietary protein, it is necessary to use peppermint essential oils supplements.

Keywords: Crude protein levels, Essential oil, Intestinal morphology, Microbial population, Nano-capsulation

(C) Ankara University, Faculty of Agriculture

\section{Introduction}

Recently, the use of medicinal plants in poultry diets has been on the rise (Darabighane et al. 2017; Gadde et al. 2017). Medicinal plants are added to poultry diets for a variety of reasons. These include antimicrobial, antioxidant, growth enhancement, reducing drug use and chemical additives, improving the taste and marketability of poultry products, and improving blood parameters and immunity (Habibi \& Ghahtan 2019; Moryani et al. 2020). Among the high-quality and widely used plants in this field, we can mention the medicinal plants of thyme and mint (Hassan 2019; Nouri 2019). Different types of thyme and mint essential oil are special importance due to their abundant contains of active ingredients such as menthol, carvone, limonene, $\beta$-pinene, menthone, $\alpha$ - pinene, geraniol, and effective drug combinations (Rabiei et al. 2011; Morsy 2017; Tariq et al. 2019; Aydin \& Barbas 2020). In order to save on essential oil consumption and make it more effective, the use of encapsulated forms of various medicinal plants, including thyme, has become common, and it show promising results in the field of working with medicinal plants (Hosseini \& Banabazi 2020; Maty \& Hassan 2020).

Since protein is an expensive part of the diet and its excretion into the environment causes many environmental problems, in recent years special attention has been paid to reducing the crude protein content of animal rations by responsible institutions and breeders. Since reducing the level of crude protein in poultry rations has adverse effects such as reduces growth, reduces production, weakens the immune system, so this reduction should be in accordance with the criteria and the use of instructions that while achieving the above, animal performance should not be reduced (Shazali et al. 2019; UlAbiden et al. 2019).

Nanotechnology is a general term that refers to all advanced technologies in the field of nanoscale work. Nanocapsules, are capsules that have a nanometer diameter and can be inserted and encapsulated (Ji et al. 2019; Elbaz et al. 2020). Nanocapsuling of aromatic substances can improves the healing properties and facilitates their access. Because of their small size, these substances increase the mechanism of cell uptake and increase their efficiency (Bayramzadeh et al. 2019). Present 
experiment carried out to evaluate the effects of using normal and nano-capsulated thyme and peppermint essential oils on intestinal morphology and microbial population of broiler with standard and low crude protein diets.

\section{Material and Methods}

A total of 320 male Ross-308 broilers (one-day-old) were sexed and weighed before starting the trial, then were divided into $2 \times 2 \times 2$ factorial experiments consisting of thyme essential oils $(0,0.2 \mathrm{~mL}$ normal and capsulated), peppermint essential oils $(0$, $0.2 \mathrm{~mL}$ normal and capsulated) and crude protein (standard and 10\% lower) with 32 units. For copulating, the loading capacity of essential oil at a concentration of $0.5-2 \%$ sodium alginate was first investigated, then was encapsulated with biocompatible calcium alginate hydrogel (Dima et al. 2013). Experiment was conducted in a completely randomized design with three growth periods including starter ( 1 to 10 days), growing (11 to 24 days) and finisher ( 25 to 42 days). Diets were formulated using the user-friendly feed formulation (UFFDA) program according to the Ross-308 broiler nutrition specification guidelines.

Table 1- Calculated nutrient contents of diets used in broilers

\begin{tabular}{|c|c|c|c|c|c|c|}
\hline \multirow{3}{*}{ Feed ingredients } & \multicolumn{6}{|c|}{ Feeding periods } \\
\hline & \multicolumn{2}{|c|}{ Starter (1 to 10 days) } & \multicolumn{2}{|c|}{ Grower (11 to 24 days) } & \multicolumn{2}{|c|}{ Finisher (25 to 42 days) } \\
\hline & Standard $C P$ & $10 \%$ Lower & Standard $C P$ & $10 \%$ Lower & Standard $C P$ & $10 \%$ Lower \\
\hline Corn & 58.0 & 63.3 & 61.7 & 60.6 & 65.5 & 69.0 \\
\hline Soybean meal & 37.1 & 31.8 & 32.8 & 28.0 & 28.0 & 24.0 \\
\hline Canola oil & 1.4 & 1.4 & 2.1 & 2.5 & 3.0 & 3.5 \\
\hline Dicalcium phosphate & 2.3 & 2.3 & 2.3 & 2.3 & 2.3 & 2.3 \\
\hline Salt & 0.3 & 0.3 & 0.3 & 0.3 & 0.3 & 0.3 \\
\hline Vitamin suppliment ${ }^{1}$ & 0.25 & 0.25 & 0.2 & 0.25 & 0.25 & 0.25 \\
\hline Mineral supplement ${ }^{2}$ & 0.25 & 0.25 & 0.2 & 0.25 & 0.25 & 0.25 \\
\hline L-Lysine hydrochloride & 0.1 & 0.1 & 0.1 & 0.1 & 0.1 & 0.1 \\
\hline DL- Methionine & 0.3 & 0.3 & 0.3 & 0.3 & 0.3 & 0.3 \\
\hline Calculated nutrients $(\%)$ & & & & & & \\
\hline $\begin{array}{l}\text { Metabolizable energy } \\
\text { (Kilocalorie per } \mathrm{Kg} \text { ) }\end{array}$ & 3000 & 3000 & 3100 & 3100 & 3200 & 3200 \\
\hline Crude protein $(\%)$ & 23.2 & 20.7 & 21.5 & 19.35 & 19.5 & 17.55 \\
\hline Calcium (\%) & 0.81 & 0.74 & 0.45 & 0.55 & 0.56 & 0.54 \\
\hline Available phosphor(\%) & 0.5 & 0.5 & 0.54 & 0.54 & 0.53 & 0.63 \\
\hline Sodium $(\%)$ & 0.19 & 0.19 & 0.18 & 0.17 & 0.18 & 0.16 \\
\hline Available Lysine $(\%)$ & 1.17 & 1.24 & 1.05 & 1.05 & 0.93 & 0.93 \\
\hline AvailableMethionine + Cystine $(\%)$ & 0.63 & 0.63 & 0.59 & 0.59 & 0.53 & 0.49 \\
\hline
\end{tabular}

${ }^{1}$ Composition of the supplement of used vitamins per Kg including: Vitamin A (IU) 22500, Vitamin $\mathrm{D}_{3}$ (IU) 5000, Vitamin E (IU)45, Vitamin K (mg) 5, Vitamin B1 (mg) 4.3, Vitamin B 2 (mg) 16.5, Vitamin B12 (mg) 0.04, Acid Pentatonic (mg) 24.5, Acid Folic (mg) 2.5, Niacin (mg) 74, Pyridoxine (mg) 7.3, Biotin (mg) 0.04. ${ }^{2}$ Composition of the supplement of used minerals per Kg including: Manganese sulfate (mg) 248, ferrous sulfate (mg) 125, zinc oxide (mg) 211, copper sulfate (mg) 25, iodate Calcium (mg) 25, Selenium (mg) 0.5, Colin (mg) 625, anti-oxidation (mg) 2.5

At the end of the experiment (42 days old), after 6 hours of starvation, 2 birds (10 birds in each replicate) were selected from each cage that close to the mean weight of the cage and after slaughter, intestinal morphology and microbial population were evaluated.

Data were subjected to statistical analysis according to a completely randomized design as a factorial arrangement of $2 \times 2 \times 2$ using the general linear model procedure of SAS (9.2). Data were log-transformed before analysing in case of unequal variances (Hosseinpour et al., 2018). Means were compared using Tukey's tests at 5\% probability, according to the following model:

$\mathrm{Y}_{\mathrm{ijkl}}=\mu+\mathrm{A}_{\mathrm{i}}+\mathrm{B}_{\mathrm{j}}+\mathrm{C}_{\mathrm{k}}+\mathrm{AB}_{\mathrm{ij}}+\mathrm{AC}_{\mathrm{ik}}+\mathrm{BC}_{\mathrm{jk}}+\mathrm{ABC}_{\mathrm{ijk}}+\varepsilon_{\mathrm{ijkl}}$

Where; $\mathrm{Y}_{\mathrm{ijkl}}$ : dependent variable; $\mu$ : overall mean; $\mathrm{A}_{\mathrm{i}}$ : the effect of thyme essential oils; $\mathrm{B}_{\mathrm{j}}$ : the effect of peppermint essential oils; $\mathrm{C}_{\mathrm{k}}$ : the effect of crude protein levels; $\mathrm{AB}_{\mathrm{ij}}$ : Interaction of Factors $\mathrm{A} \times \mathrm{B} ; \mathrm{AC}_{\mathrm{ik}}$ : Interaction of Factors $\mathrm{A} \times \mathrm{C}$; $\mathrm{BC}_{\mathrm{jk}}$ : Interactivity of Factors $\mathrm{B} \times \mathrm{C}$; $\mathrm{ABC}_{\mathrm{ijk}}$ : Interaction of Factors $\mathrm{A} \times \mathrm{B} \times \mathrm{C}$ and $\varepsilon_{\mathrm{ijkl}}=$ the random error.

\section{Results and Discussion}

\subsection{Intestinal morphology}

The effects of experimental treatments on intestinal morphology of broilers are presented in Table 2. Experimental treatments had no significant effects on villi and goblet cells of chickens, but resulted in changing the crypt and villi/crypt parameters, and the difference between means was statistically significant $(\mathrm{P}<0.05)$. Capsulation in contrast to non-capsulation, significantly increased the depth of crypts and reduced the ratio of villi to crypt $(\mathrm{P}>0.05)$. In interaction between diet crude protein and 
medicinal plant, using standard protein with thyme had the best result about crypt depth and villi height. About interaction between diet protein level and capsulation, the best result about crypt depth and villi height was observed with normal protein level and no capsulated form of oils. In interaction between medicinal plant essential oil and form of use, the lowest crypt depth was resulted in group with normal crude protein level and non-capsulated. Thyme with non-capsulated form of oil had the lowest crypt depth $(\mathrm{P}>0.05)$. In interaction between diet crude protein level, medicinal plant essential oil and form of application, the best result was obtained with normal level of crude protein, thyme essential oil and non-capsulated forms of them (P.0.05). Among the crypt and villi/crypt parameters related to interactions (protein levels and essential oil type), the use of peppermint essential oil with normal protein, crypt depth increased and the ratio of villi height to crypt depth was minimal $(\mathrm{P}<0.05)$.

In an experiment was conducted by using thyme and oregano extracts on intestinal morphology, observed that the mixture of these herbal extracts effectively increased the heights of villi cells and reduced the numbers of goblets (Manafi et al. 2018). The antimicrobial properties of thyme were reported by many researchers.

Table 2- Effect of experimental treatments on intestinal morphology $(\mu \mathrm{m})$

\begin{tabular}{|c|c|c|c|c|}
\hline Effects & Villi & Crypt & Villi/Crypt & Goblet Cells \\
\hline \multicolumn{5}{|l|}{ Protein } \\
\hline Abnormal & 1117.8 & 173.2 & 6.4 & 42.1 \\
\hline Normal & 1124.1 & 176.2 & 6.7 & 45.8 \\
\hline SEM & 26.39 & 2.65 & 0.15 & 2.10 \\
\hline P-value & 0.867 & 0.425 & 0.395 & 0.223 \\
\hline \multicolumn{5}{|l|}{ Medicinal plant } \\
\hline Peppermint & 1144.8 & 183.8 & 6.6 & 46.1 \\
\hline Thyme & 1097.2 & 165.7 & 6.6 & 41.7 \\
\hline SEM & 26.39 & 2.64 & 0.15 & 2.08 \\
\hline P-value & 0.215 & $<0.0001$ & 0.969 & 0.156 \\
\hline \multicolumn{5}{|l|}{ Capsulation } \\
\hline Capsulated & 1103.0 & $181.6^{\mathrm{a}}$ & $6.1^{\mathrm{b}}$ & 44.9 \\
\hline non-capsulated & 1138.9 & $167.8^{\mathrm{b}}$ & $6.9^{\mathrm{a}}$ & 42.9 \\
\hline SEM & 26.39 & 2.64 & 0.15 & 2.08 \\
\hline P-value & 0.345 & 0.001 & 0.0009 & 0.517 \\
\hline \multicolumn{5}{|l|}{ Protein $\times$ Medicinalplant } \\
\hline Abnormal $\times$ Peppermint & 1128.1 & $184.2^{\mathrm{a}}$ & $6.2^{\mathrm{b}}$ & 44.6 \\
\hline Abnormal $\times$ Thyme & 1107.5 & $162.2^{\mathrm{c}}$ & $6.7^{\mathrm{ab}}$ & 39.5 \\
\hline Normal $\times$ Peppermint & 1161.4 & $183.3^{\mathrm{ab}}$ & $6.9^{\mathrm{a}}$ & 47.5 \\
\hline Normal×Thyme & 1086.8 & $169.1^{\mathrm{bc}}$ & $6.4^{\mathrm{ab}}$ & 44.0 \\
\hline SEM & 37.32 & 3.74 & 0.22 & 2.94 \\
\hline $\mathrm{P}$-value & 0.477 & 0.031 & 0.016 & 0.785 \\
\hline \multicolumn{5}{|l|}{ Protein $\times$ Capsulation } \\
\hline Abnormal $\times$ Capsulated & 1092.6 & $179.2^{\mathrm{ab}}$ & $6.0^{\mathrm{b}}$ & 44.4 \\
\hline Abnormal $\times$ non-capsulated & 1143.0 & 167. $2^{\mathrm{b}}$ & $6.9^{\mathrm{a}}$ & 39.7 \\
\hline Normal $\times$ Capsulated & 1113.3 & $184.0^{\mathrm{a}}$ & $6.2^{\mathrm{ab}}$ & 45.4 \\
\hline Normal $\times$ non-capsulated & 1134.9 & $168.5^{\mathrm{b}}$ & $7.0^{\mathrm{a}}$ & 46.1 \\
\hline SEM & 37.32 & 3.74 & 0.22 & 2.95 \\
\hline P-value & 0.703 & 0.050 & 0.043 & 0.371 \\
\hline \multicolumn{5}{|l|}{ Medicinal plant $\times$ Capsulation } \\
\hline Peppermint $\times$ Capsulated & 1111.2 & $186.8^{\mathrm{a}}$ & 6.1 & 44.1 \\
\hline Peppermint $\times$ non-capsulated & 1178.2 & $180.7^{\mathrm{a}}$ & 6.9 & 48.0 \\
\hline Thyme $\times$ Capsulated & 1094.7 & $176.4^{\mathrm{a}}$ & 6.1 & 45.6 \\
\hline Thyme $\times$ non-capsulated & 1099.6 & $154.9^{\mathrm{b}}$ & 6.9 & 37.9 \\
\hline SEM & 37.32 & 3.74 & 0.22 & 2.95 \\
\hline P-value & 0.414 & 0.050 & 0.948 & 0.060 \\
\hline \multicolumn{5}{|l|}{ Protein $\times$ Medicinal plant $\times$ Capsulation } \\
\hline Abnormal $\times$ Peppermint $\times$ Capsulated & 1046.0 & $182.5^{\mathrm{ab}}$ & 5.8 & 44.5 \\
\hline Abnormal $\times$ Peppermint $\times$ non-capsulated & 1210.2 & $185.8^{\mathrm{ab}}$ & 6.6 & 44.7 \\
\hline Abnormal $\times$ Thyme $\times$ Capsulated & 1139.2 & $175.9^{\mathrm{ab}}$ & 6.3 & 44.2 \\
\hline Abnormal $\times$ Thyme $\times$ non-capsulated & 1075.7 & $148.5^{\mathrm{c}}$ & 7.2 & 34.7 \\
\hline Normal $\times$ Peppermint $\times$ Capsulated & 1176.5 & $191.0^{\mathrm{a}}$ & 6.5 & 43.7 \\
\hline Normal $\times$ Peppermint $\times$ non-capsulated & 1146.2 & $175.6^{\mathrm{ab}}$ & 7.3 & 51.2 \\
\hline Normal $\times$ Thyme $\times$ Capsulated & 1050.2 & $176.9^{\mathrm{ab}}$ & 5.9 & 47.0 \\
\hline Normal $\times$ Thyme $\times$ non-capsulated & 1123.5 & $161.3^{\mathrm{bc}}$ & 6.7 & 41.0 \\
\hline SEM & 52.78 & 5.26 & 0.31 & 4.17 \\
\hline P-value & 0.362 & 0.048 & 0.828 & 0.753 \\
\hline
\end{tabular}


Since the villi of the gastrointestinal tract are the first place to communicate with nutrients, they play a very important role in digestion and absorption of the small intestine (Sohel et al. 2019; Reynolds et al. 2020). An increase in villi height means an increase in intestinal absorption, and a decrease in crypt depth indicates a decrease in replacement of enterocytes, and a decrease in tissue changes. In other words, increasing the height of the villi and the depth of the crypt are directly related to the increase in renewal in epithelial cells (Rubin \& Levin 2016; Martin et al. 2017; Khan et al. 2020).

\subsection{Microbial characteristics of the intestine}

The effects of experimental treatments on intestinal microbiology are presented in Table 3 . In relation to the effects of experimental diets on the beneficial microbial population of small intestine in chickens, a decrease in the level of crude protein in diets reduced the population of lactobacilli in the intestine $(\mathrm{P}<0.05)$. The type and form of essential oils did not have significant effects on the microbial population of small intestine $(\mathrm{P}>0.05)$. Regarding the interactional effects of experimental materials on the microbial population of small intestine of chickens, the use of normal protein levels along with thyme essential oil increased the population of lactobacilli and the overall form in the intestines of chickens $(\mathrm{P}<0.05)$. However, the level of crude protein in the diet and the form of use of the essential oil, as well as the type of essential oil and its form did not have significant effects on the microbial population of the intestine $(\mathrm{P}<0.05)$. In the study of the three-way effects between the level of crude protein, the type and form of essential oil, the use of normal protein level with the encapsulated form of thyme essential oil, the total microbial population of form and lactobacilli was at its maximum $(\mathrm{P}<0.05)$. 
Table 3- Effect of experimental treatments on intestinal microbiology (CFU/gr)

\begin{tabular}{|c|c|c|}
\hline Effects & Lactobacylus & Choliform \\
\hline \multicolumn{3}{|l|}{ Protein } \\
\hline Abnormal & $3.78^{\mathrm{b}}$ & 5.35 \\
\hline Normal & $4.95^{\mathrm{a}}$ & 5.53 \\
\hline SEM & 0.311 & 0.365 \\
\hline $\mathrm{P}$-value & 0.013 & 0.713 \\
\hline \multicolumn{3}{|l|}{ Medicinal plant } \\
\hline Peppermint & 4.22 & 5.32 \\
\hline Thyme & 4.51 & 5.56 \\
\hline SEM & 0.311 & 0.365 \\
\hline P-value & 0.514 & 0.654 \\
\hline \multicolumn{3}{|l|}{ Capsulation } \\
\hline Capsulated & 4.00 & 5.64 \\
\hline non-capsulated & 4.72 & 5.24 \\
\hline SEM & 0.311 & 0.365 \\
\hline P-value & 0.112 & 0.437 \\
\hline \multicolumn{3}{|l|}{ Protein $\times$ Medicinal plant } \\
\hline Abnormal $\times$ Peppermint & $4.00^{\mathrm{ab}}$ & $5.83^{b}$ \\
\hline Abnormal $\times$ Thyme & $3.55^{\mathrm{b}}$ & $4.85^{\mathrm{b}}$ \\
\hline Normal $\times$ Peppermint & $4.43^{\mathrm{ab}}$ & $4.81^{b}$ \\
\hline Normal $\times$ Thyme & $5.46^{\mathrm{a}}$ & $6.26^{\mathrm{a}}$ \\
\hline SEM & 0.439 & 0.516 \\
\hline P-value & 0.032 & 0.027 \\
\hline \multicolumn{3}{|l|}{ Protein $\times$ Capsulation } \\
\hline Abnormal $\times$ Capsulated & 3.25 & 5.86 \\
\hline Abnormal $\times$ non-capsulated & 4.30 & 4.83 \\
\hline Normal $\times$ Capsulated & 4.75 & 5.43 \\
\hline Normal $\times$ non-capsulated & 5.14 & 5.64 \\
\hline SEM & 0.439 & 0.516 \\
\hline P-value & 0.459 & 0.240 \\
\hline \multicolumn{3}{|l|}{ Medicinal plant $\times$ Capsulation } \\
\hline Peppermint $\times$ Capsulated & 3.75 & 5.51 \\
\hline Peppermint $\times$ non-capsulated & 4.69 & 5.13 \\
\hline Thyme $\times$ Capsulated & 4.25 & 5.77 \\
\hline Thyme $\times$ non-capsulated & 4.762 & 5.34 \\
\hline SEM & 0.439 & 0.516 \\
\hline P-value & 0.629 & 0.965 \\
\hline \multicolumn{3}{|l|}{ Protein $\times$ Medicinal plant $\times$ Capsulation } \\
\hline Abnormal $\times$ Peppermint $\times$ Capsulated & $3.71^{\mathrm{ab}}$ & $6.99^{\mathrm{a}}$ \\
\hline Abnormal $\times$ Peppermint $\times$ non-capsulated & $4.29^{\mathrm{ab}}$ & $4.67^{\mathrm{ab}}$ \\
\hline Abnormal $\times$ Thyme $\times$ Capsulated & $2.78^{b}$ & $4.72^{\mathrm{ab}}$ \\
\hline Abnormal $\times$ Thyme $\times$ non-capsulated & $4.32^{\mathrm{ab}}$ & $4.99^{\mathrm{ab}}$ \\
\hline Normal $\times$ Peppermint $\times$ Capsulated & $3.78^{\mathrm{ab}}$ & $4.03^{\mathrm{b}}$ \\
\hline Normal $\times$ Peppermint $\times$ non-capsulated & $5.08^{\mathrm{ab}}$ & $5.59^{\mathrm{ab}}$ \\
\hline Normal $\times$ Thyme $\times$ Capsulated & $5.72^{\mathrm{a}}$ & $6.82^{\mathrm{a}}$ \\
\hline Normal $\times$ Thyme $\times$ non-capsulated & $5.21^{\mathrm{ab}}$ & $5.69^{\mathrm{ab}}$ \\
\hline SEM & 0.621 & 0.729 \\
\hline P-value & 0.013 & 0.017 \\
\hline
\end{tabular}

a, b, c: Values within a row with different superscripts differ significantly at $\mathrm{P}<0.05$

Numerous studies have shown the antimicrobial properties of plant extracts that can improve the flora and intestinal health of the bird's digestive tract by reducing the number of pathogenic bacteria (Ebrahimi et al. 2016; Yadav et al. 2016; Jin et al. 2020). Disadvantages include the presence of harmful microbes in the gastrointestinal tract, increased protein and amino acid degradation due to the secretion of substances such as urease enzymes by microbes (Sharma et al. 2019; Thapa et al. 2019). On the base of Hajipour et al. (2015) study, using thyme powder and essential oils in broilers diets significantly increased the lactobacilli population and reduced the numbers of E coli, also there have beneficial effect on intestinal cells morphology, So the highest villi and the lowest depth of crypt cells blogged to thyme treatments. Using capsulated form of oregano essential oil in contrast to normal form can improve the intestine microbial population and health status of broilers (Ghasemloo et al. 2017). Recently on the base of Mahdavi \& Nobakht (2018) study, the mixture of thyme and ziziphora extracts and increase the population of lactobacillus and reduced of E coli numbers in broiler digestive tract. As a result, the use of medicinal plants 
essential oils was reduced the gram-negative microbial population of the gastrointestinal tract, so the rate of proteins and amino acids degradation were decreased and more of them are absorbed and stored in the body.

\section{Conclusions}

Based on the results of this experiment, it can be stated that in broilers, the capsulated form of dietary thyme essential oil with standard crude protein level improved intestinal morphology and changed microbial population on the behalf of Lactobacillus. Also, a 10 percent reduction in the level of crude protein in the diet had adverse effects on measured traits and should be not recommended.

\section{Acknowledgements}

The research animal ethics committee of Islamic Azad university approved this experimental protocol. The article was extracted from the Ph.D. thesis prepared by Mohammad Reza Alie-Laleh, under supervision of Prof. Ali Nobakht.

\section{References}

Aydı B \& Barbas L A L (2020). Sedative and anesthetic properties of essential oils and their active compounds in fish: A review. Aquaculture 520: 734999. https://doi.org/10.1016/j.aquaculture.2020.734999

Bayramzadeh N, Mehrkhou F, Pourmirza A A \& Mahmoudian M (2019). Fumigant toxicity of two nano-capsulated essential oils with sublethal rate of phosphine against three stored-product pests. Journal of Agricultural Science and Technology 21(4): 857-872

Darabighane B, Mirzaei Aghjeh Gheshlagh F, Navidshad B, Mahdavi A, Zarei A \& Nahashon S (2017). Effects of peppermint (Menthapiperita) and Aloe vera (Aloe barbadensis) on ileum microflora population and growth performance of broiler chickens in comparison with antibiotic growth promoter. Iranian Journal of Applied Animal Science 7(1): 101-108. https://doi.org/10.1080/09712119.2011.620435

Dima C, Gitin L, Alexe P \& Dima S (2013). Encapsulation of coriander essential oil in alginate and alginate/chitosan microspheres by emulsification external gelation method. Inside Food Symposium 9: 1-6

Ebrahimi H, Rahimi S, Khaki P, Grimes J L \& Kathariou S (2016). The effects of probiotics, organic acid, and a medicinal plant on the immune systemand gastrointestinal microflora in broilers challenged with Campylobacter jejuni. Turkish Journal of Veterinary and Animal Sciences 40(3): 329-336. https://doi.org/10.3906/vet-1502-68

Elbaz N M, Owen A, Rannard S \& McDonald T O (2020). Controlled synthesis of calcium carbonate nanoparticles and stimuli-responsive multi-layered nanocapsules for oral drug delivery. International Journal of Pharmaceutics 574: 118866. https://doi.org/10.1016/j.ijpharm.2019.118866

Gadde U, Kim W H, Oh S T \& Lillehoj H S (2017). Alternatives to antibiotics for maximizing growth performance and feed efficiency in poultry: a review. Animal Health Research Reviews 18(1): 26-45. https://doi.org/10.1017/s1466252316000207

Ghasemloo V, Hosseini SA, Lotfollahian H \& Meimandipour A (2017). The effects of encapsulated oregano essential oil on microbial population and morphology of intestinal tract in broiler chickens. Journal of Animal Production 19(2): 467-478. https://doi.org/10.22059/jap.2017.62175

Habibi H \& Ghahtan N (2019). Evaluation of the use of some medicinal plants as diet additive on carcass quality, microbial count and immune responses in Japanese Quail. Poultry Science Journal 7(2): 141-150. https://doi.org/10.22069/PSJ.2019.16579.1447

Hajipour S H, Afsharmanesh M, Sami M \& Khabazzadeh H (2015). Effects of thyme leaves powder and its essential oil on performance, meat quality and intestinal characteristics of meat type quails. Iranian Journal of Animal Sciences 45(4): 353-361. https://doi.org/10.22059/IJAS.2014.54356

Hassan H A (2019). Effects of Thyme oil, peppermint oil and their combination on productive performance, carcass criteria and blood profile of broiler chickens. Journal of Animal and Poultry Production 10(5): 105-108. https://doi.org/10.21608/jappmu.2019.43000

Hosseini S A \& Banabazi M H (2020). Effects of dietary Inclusion of the encapsulated thyme and oregano essential oils mixture and probiotic on growth performance, immune response and intestinal morphology of broiler chickens. Poultry Science Journal 8(1): 17-25. https://doi.org/10.22069/psj.2020.17101.1497

Hosseinpour S, Alavi Milani MMR \& Pehlivan H (2018) A Step-by-step solution methodology for mathematical expressions. Symmetry 10(7): 285. https://doi.org/10.3390/sym10070285

Ji W, Zhang T, Lu Z, Shen J, Xiao Z \& Zhang X (2019). Synthesis and characterization of novel biocompatible nanocapsules encapsulated lily fragrance. Chinese Chemical Letters 30(3): 739-742. https://doi.org/10.1016/j.cclet.2018.09.008

Jin L Z, Dersjant-Li Y \& Giannenas I (2020). Application of aromatic plants and their extracts in diets of broiler chickens. In Feed Additives (pp. 159-185). Academic Press. https://doi.org/10.1016/B978-0-12-814700-9.00010-8

Khan M, Anjum A A, Nawaz M, Awan A R \& Ali M A (2020). Effect of Lactobacillus gallinarum PL 53 Supplementation on xylose absorption and intestinal morphology in broilers challenged with campylobacter jejuni. Pakistan Veterinary Journal 40(2): 163-168. https://doi.org/10.29261/pakvetj/2020.011

Mahdavi S \& Nobakht A (2018) Evaluation of the effect of thyme (Thymus vulgaris L.) and ziziphora (Ziziphora tenuri L.) essential oils on intestinal microflora of broilers. Veterinary Clinical Pathology 11(44): 305-3013

Manafi M, Hedayati M \& Arak H (2018). The effect of concomitant use of ethanolic mixture extractions of Thyme and Oregano on performance and morphology of gastrointestinal tract in broilers fed contaminated feed with Aflatoxin B1. Journal of Animal Science Research 28(3): 1-16

Martin C R, Stoll B, Cluette-Brown J, Akinkuotu A C, Olutoye O O, Gura K M \& Freedman S D (2017). Use of a novel docosahexaenoic acid formulation vs control in a neonatal porcine model of short bowel syndrome leads to greater intestinal absorption and higher systemic levels of DHA. Nutrition Research 39: 51-60. https://doi.org/10.1016/j.nutres.2017.02.004

Maty H N \& Hassan A A (2020). Effect of supplementation of encapsulated organic acid and essential oil Gallant $+[$ on some physiological parameters of Japanese quails. Iraqi Journal of Veterinary Sciences 34(1): 181-188. https://doi.org/10.33899/ijvs.2019.125732.1142 
Morsy N F S (2017). Chemical structure, quality indices and bioactivity of essential oil constituents. Active Ingredients from Aromatic and Medicinal Plants; InTech: London, UK 175-206. http://dx.doi.org/10.5772/66231

Moryani A A, Rajput N, Rajput M N \& Shah A H (2020). 114. Prevalence of common poultry diseases in chicken and influence of different medicinal herbs on the growth of broiler chicken. Pure and Applied Biology 9(1): 1199-1208. http://dx.doi.org/10.19045/bspab.2020.90126

Nouri A (2019). Chitosan nano-encapsulation improves the effects of mint, thyme, and cinnamon essential oils in broiler chickens. British Poultry Science 60(5): 530-538. https://doi.org/10.1080/00071668.2019.1622078

Rabiei V, Shirzadeh E, Rabbi Angourani H \& Sharafi Y (2011). Effect of thyme and lavender essential oils on the qualitative and quantitative traits and storage life of apple Jonagold cultivar. Journal of Medicinal Plants Research 5(23): 5522-5527

Reynolds K L, Cloft S E \& Wong E A (2020). Changes with age in density of goblet cells in the small intestine of broiler chicks. Poultry Science 99(5): 2342-2348. https://doi.org/10.1016/j.psj.2019.12.052

Rubin D C \& Levin M S (2016). Mechanisms of intestinal adaptation. Best practice \& Research Clinical gastroenterology 30(2): 237-248. https://doi.org/10.1016/j.bpg.2016.03.007

Sharma P, Slathia P S, Raina N \& Bhagat D (2019). Microbial diversity in freshwater ecosystems and its industrial potential. In Freshwater Microbiology (pp. 341-392). Academic Press. https://doi.org/10.1016/B978-0-12-817495-1.00009-8

Shazali N, Loh T C, Foo H L \& Samsudin A A (2019). Gut microflora and intestinal morphology changes of broiler chickens fed reducing dietary protein supplemented with lysine, methionine, and threonine in tropical environment. Revista Brasileira de Zootecnia 48: e20170265. https://doi.org/10.1590/rbz4820170265

Sohel M S H, Miah M H, Faruq A A, Rahman M L \& Islam K N (2019). Development of small intestinal morphology on the basis of growth and absorption rate in Broiler chicken (Cobb 500) of Bangladesh. Bangladesh Journal of Veterinary and Animal Sciences 7(1): 9-14

Tariq S, Wani S, Rasool W, Shafi K, Bhat M A, Prabhakar A \& Rather M A (2019). A comprehensive review of the antibacterial, antifungal and antiviral potential of essential oils and their chemical constituents against drug-resistant microbial pathogens. Microbial pathogenesis 134: 103580. https://doi.org/10.1016/j.micpath.2019.103580

Thapa S, Li H, OHair J, Bhatti S, Chen F C, Al Nasr K \& Zhou S (2019). Biochemical Characteristics of Microbial Enzymes and Their Significance from Industrial Perspectives. Molecular biotechnology 1-23. https://doi.org/10.1007/s12033-019-00187-1

UlAbiden M Z, Ali M, Yaqoob M U, Jamal A, Subhani A \& Irfan A (2019). Effect of replacing different level of Crude Protein with Synthetic Amino acids on Growth Performance, Carcass Traits and Nutrient Digestibility in Broilers. Journal of Biotechnology and Recent Advances 2(1): 64-67. https://doi.org/10.18689/ijbr-1000111

Yadav A S, Kolluri G, Gopi M, Karthik K \& Singh Y (2016). Exploring alternatives to antibiotics as health promoting agents in poultry-a review. The Journal of Experimental Biology 4(3S-10.18006) 3S. http://dx.doi.org/10.18006/2016.4(3S).368.383

(C) 2022 by the author(s). Published by Ankara University, Faculty of Agriculture, Ankara, Turkey. This is an Open Access article distributed under the terms and conditions of the Creative Commons Attribution (CC BY) license (http://creativecommons.org/licenses/by/4.0/), which permits unrestricted use, distribution, and reproduction in any medium, provided the original work is properly cited. 